\title{
UTRZYMANIE PŁYNNOŚCI FINANSOWEJ W PRZEDSIĘBIORSTWIE JAKO WARUNEK KONTYNUACJI JEGO DZIAŁALNOŚCI NA PRZYKŁADZIE ZAKŁADÓW MIĘSNYCH HENRYK KANIA S.A.
}

\section{Andrzej Kuciński*}

\section{MAINTAINING FINANCIAL LIQUIDITY IN THE ENTERPRISE \\ AS A CONDITION FOR THE CONTINUATION OF ITS ACTIVITIES ON THE EXAMPLE OF ZAKŁADY MIĘSNE HENRYK KANIA S.A.}

\begin{abstract}
In an environment of increased uncertainty, in which modern enterprises have to operate, maintaining financial liquidity is a priority. Having financial liquidity by the enterprise determines the continuity of operations and its development. In the article, on the basis of the case study of the company Zakłady Mięsne Henryk Kania S.A., the shaping of the company's payment capacity in 2015-2019 was analyzed using the short-term and long-term approach in the assessment of financial liquidity. The shown example shows that problems related to maintaining liquidity in an enterprise may lead to the bankruptcy of the enterprise.
\end{abstract}

Keywords: financial liquidity, payment capacity, enterprise.

JEL Class: G32.

\footnotetext{
* Doktor, Wydział Ekonomiczny, Akademia im. Jakuba z Paradyża w Gorzowie Wielkopolskim; https://orcid.org/0000-00028988-8872.
} 


\section{WSTĘP}

Wzrost niepewności, który dotyka współczesne przedsiębiorstwa, wprowadza do ich działalności wiele niewiadomych przekładających się na zwiększoną zmienność uzyskiwanych wyników, w tym na wzrost ryzyka utraty płynności finansowej. W praktyce można zaobserwować, że wraz z pogarszającymi się warunkami gospodarczymi rośnie liczba upadających przedsiębiorstw, których główną przyczyną są problemy z utrzymaniem płynności finansowej.

Współczesne przedsiębiorstwa nie koncentrują się dziś wyłącznie na rentowności, dla większości z nich równie ważną kategorią jak zysk jest płynność finansowa. Te przedsiębiorstwa, które w praktyce postępują inaczej doświadczają sytuacji utraty płynności finansowej pomimo osiąganej rentowności. Przedsiębiorstwa upadają zwykle nie z powodu braku zysku, lecz w wyniku utraty zdolności płatniczej.

Do zadań każdego przedsiębiorstwa należy monitorowanie płynności finansowej, a jej utrzymanie należy do najważniejszych krótkoterminowych celów zarządzania finansami w przedsiębiorstwie. Utrata zdolności do regulowania bieżących zobowiązań przez przedsiębiorstwo przekłada się na jego problemy związane $\mathrm{z}$ zachowaniem zdolności operacyjnej, ale jednocześnie wywołuje wiele innych negatywnych skutków, w tym również tych o charakterze strategicznym, m.in. ograniczając zdolności inwestycyjne przedsiębiorstwa. To wymusza na zarządzających koncentrację na problemie zachowania zdolności płatniczej przedsiębiorstwa zarówno w ujęciu krótkoterminowym, jak i długoterminowym, w celu zapewnienia jednostce gospodarczej sprawności operacyjnej oraz właściwych warunków do wypracowywania zysków w długim okresie.

Celem niniejszego artykułu jest ocena płynności finansowej przedsiębiorstwa Henryk Kania S.A. w latach 2015-2019 oraz weryfikacja tego czy na podstawie analizy płynności finansowej przedsiębiorstwa możliwa jest ocena zagrożenia ryzykiem do kontynuowania jego działalności. W opracowaniu za hipotezę badawczą przyjęto, że utrata płynności finansowej przez przedsiębiorstwo prowadzi do jego upadłości.

Badanie przeprowadzono na podstawie przedsiębiorstwa ZM Henryk Kania S.A. Przyjęty horyzont analizy obejmował lata 2015-2019. Do realizacji przyjętego celu i weryfikacji hipotezy wykorzystano jako główną metodę badawczą analizę danych finansowych z rocznych sprawozdań finansowych badanej spółki.

\section{WYBRANE ASPEKTY PŁYNNOŚCI FINANSOWEJ ORAZ PRZEGLĄD LITERATURY}

Przedsiębiorstwa funkcjonujące w ramach gospodarki rynkowej są pod wpływem oddziaływania różnych czynników, które decydują o ich dalszym istnieniu na rynku. Do grupy zasadniczych czynników determinujących funkcjonowanie 
przedsiębiorstwa należy zaliczyć płynność finansową. Jej posiadanie warunkuje możliwość kontynuowania działalności gospodarczej.

Pojęcie płynności finansowej jest wieloznaczne, rozumiane w różny sposób, a co za tym idzie ujmowane w różnych jego aspektach. Płynność finansowa może być utożsamiana $\mathrm{z}$ płynnością posiadanego majątku, ze sprawnością zamiany składnika aktywów w środki pieniężne, strukturą majątku - tzw. ujęcie majątkowe płynności finansowej (Wędzki, 2003: 33). Ocena płynności finansowej w ramach tego podejścia wiąże się $\mathrm{z}$ analizą posiadanego majątku przez przedsiębiorstwo. Zasoby majątkowe wykorzystywane przez przedsiębiorstwo stanowią z reguły zróżnicowaną grupę składników, uzależnioną od specyfiki i przedmiotu jego działalności, które wykazywane w bilansie dzieli się na aktywa trwałe i aktywa obrotowe. O umiejscowieniu poszczególnych składników aktywów w bilansie decyduje zasada rosnącej płynności, która bezpośrednio przekłada się na płynność finansową w ujęciu strukturalnym. Zdolność płatnicza przedsiębiorstwa jest tym lepsza, im w strukturze majątku rośnie udział tych składników, które łatwo można zamienić na środki pieniężne. Stąd odwrotnie, gdy w strukturze aktywów przedsiębiorstwa przeważa majątek trwały, którego płynność jest mniejsza niż majątku obrotowego, tym gorsza ocena płynności finansowej jednostki gospodarczej (Kuciński, 2018a: 134). Wykorzystanie tego ujęcia w praktyce może utrudniać to, że przyporządkowanie danego składnika do aktywów obrotowych nie musi oznaczać ich wysokiej płynności. Posiadane zasoby mogą być trudne do upłynnienia lub w ogóle niemożliwe do zamiany na środki pieniężne m.in. z powodu braku popytu, niepłynności rynku, niemożliwości sprzedaży, utraty wartości, niewypłacalności przedsiębiorstwa itp.

Płynność finansową można rozpatrywać również w ujęciu majątkowo-kapitałowym, wówczas jest ona rozumiana jako zdolność przedsiębiorstwa do terminowego regulowania zobowiązań o charakterze krótkoterminowym (Kusak, 2006: 9). Zdolność ta wyznaczana jest z jednej strony przez płynność posiadanego majątku, a z drugiej strony przez poziom wymagalności zobowiązań, skalę zadłużenia krótkoterminowego. Aktywa przedsiębiorstwa w tym ujęciu traktowane są jako zabezpieczenie spłaty wymagalnych zobowiązań.

Przy definiowaniu płynności finansowej, bez względu na jej ujęcie, różni autorzy m.in. M. Sierpińska, T. Jachna (1993: 134), G. Michalski (2010: 38) posiłkują się terminem „zdolność”. Według R. Stępnia (2013: 97) określenia tego używa się po to, aby podkreślić, iż w gruncie rzeczy płynność finansowa jest zdolnością płatniczą, czyli gotowością przedsiębiorstwa do spłaty wymagalnych zobowiązań. Owa gotowość wyraża się poziomem zgromadzonych środków pieniężnych wykorzystywanych do regulowania zobowiązań przedsiębiorstwa, a także możliwością zamiany aktywów na środki pieniężne przed terminem spłaty zobowiązań. W praktyce podmioty gospodarcze rzadko utrzymują środki pieniężne $\mathrm{w}$ celu pełnego pokrycia zobowiązań bieżących, $\mathrm{z}$ reguły utrzymują 
pewien jej poziom, lub też dążą do równoważenia strumieni wpływów i wypływów środków pieniężnych w celu zapewnienia płynności finansowej w przedsiębiorstwie.

W ramach ujęcia majątkowo-kapitałowego płynności finansowej wyróżnić możemy płynność finansową krótkoterminową oraz długoterminową (Wędzki, 2003: 33). Wyodrębnione kategorie w odmienny sposób definiują płynność finansową. W przypadku płynności krótkoterminowej chodzi o ustalenie zdolności przedsiębiorstwa do spłaty zobowiązań bieżących na podstawie płynnych aktywów będących w posiadaniu przez przedsiębiorstwo, z kolei w przypadku płynności długoterminowej o zbadanie, w jakim stopniu wartość całego majątku przedsiębiorstwa przewyższa finansujące go zobowiązania. Płynność finansową w ujęciu długoterminowym często utożsamia się w literaturze $\mathrm{z}$ wypłacalnością, która odnosi się do zdolności, jaką posiada przedsiębiorstwo do spłaty ogółu zobowiązań (Burzykowska, 2006: 88). W myśl art. 11 ustawy Prawo upadłościowe, można ustalić przesłanki przemawiające za uznaniem przedsiębiorstwa za niewypłacalne. Są nimi przesłanki o charakterze płynnościowym (utrata zdolności do wykonywania wymagalnych zobowiązań) i zadłużeniowym (poziom zobowiązań przekracza wartość majątku przedsiębiorstwa) (Kuciński, 2018b: 122).

Statyczny obraz płynności finansowej w literaturze poddawany jest krytyce, stąd różni autorzy, m.in. L. Bednarski i T. Waśniewski uważają, że obraz płynności finansowej wyznaczany na podstawie zgromadzonych płynnych aktywów gwarantujących spłatę zobowiązań jest niewystarczający (Bednarski i Waśniewski, 1996: 333). Według I. Witczak mankamentem ujęcia statycznego jest wyznaczanie płynności finansowej przedsiębiorstwa na określony moment, którym jest zwykle dzień sporządzenia sprawozdania finansowego oraz to, że rzeczywisty obraz zdolności płatniczej jest zniekształcony przez przyjęte zasady rachunkowości i określenia wartości bilansowej (Witczak, 2014: 415). Tym samym w literaturze można odnaleźć tzw. podejście dynamiczne, w którym zwrócono szczególną uwagę na rolę rachunku przepływów pieniężnych w kształtowaniu płynności finansowej, jednocześnie $\mathrm{w}$ ten sposób podkreślając znaczenie środków pieniężnych w funkcjonowaniu i rozwoju działalności każdego przedsiębiorstwa. Płynność finansowa w ujęciu dynamicznym wyznaczają strumienie wpływów i wypływów środków pieniężnych. Płynność w tym ujęciu odnosi się do zdolności generowania przepływów pieniężnych, a nie do wartości istniejących zasobów płynnych aktywów w przedsiębiorstwie (Kusak, 2006: 11).

Niezależnie od zawiłości terminologicznych związanych z określeniem istoty płynności finansowej można przyjąć, że zachowanie zdolności do spłaty zobowiązań zarówno w krótkim, jak i długim terminie stanowi podstawowy warunek, który musi być spełniony, aby przedsiębiorstwo mogło przetrwać na rynku i kontynuować działalność w przyszłości. Ponadto zmiany w kształtowaniu się płynności finansowej przedsiębiorstwa bezpośrednio przekładają się na ryzyko 
funkcjonowania oraz jego bezpieczeństwo finansowe, z którym wiąże się poczucie i gwarancja istnienia oraz szansa na rozwój (Karbownik, 2012: 66). Tym samym płynność finansowa znajduje się w centrum uwagi zarządzających, gdyż warunkuje ona $\mathrm{w}$ dużym stopniu bezpieczeństwo finansowe przedsiębiorstwa, o które należy w sposób ciągły zabiegać.

W literaturze ekonomicznej płynność finansowa stanowi często podejmowany przedmiot rozważań, znajdujący swe odzwierciedlenie w liczbie prezentowanych publikacji. $Z$ przeprowadzonego przeglądu literatury wynika, że do zagadnień, na których często skoncentrowana jest uwaga wielu badaczy należy weryfikacja zależności miedzy rentownością a płynnością finansową. Przedmiotem tych badań były zarówno relacje występujące między statycznymi, jak i dynamicznymi miarami płynności finansowej a rentownością przedsiębiorstwa. Znaczna część opublikowanych wyników badań wskazuje na istnienie negatywnego związku między płynnością a rentownością. Ujemną zależność potwierdziły badania m.in. B. Guzika (2006: 67), który jest zdania, że płynność jest jedną z wielu zmiennych objaśniających rentowność banków. T. Waściński i M. Kruk (2010: 19) są podobnego zdania, którzy na przykładzie spółek z branży cukierniczej notowanych na GPW w Warszawie wykazali negatywny wpływ płynności na rentowność. Z kolei M. Bolek i W. Wiliński (2012: 51) na podstawie spółek z sektora budowlanego notowanych na GPW w Warszawie udowodnili, że wśród zmiennych reprezentujących płynność finansową wskaźnik QR (wskaźnik płynności szybkiej) był istotny statystycznie i negatywnie wpływał na rentowność majątku (ROA). Oczywiście nie brakuje również ustaleń odwrotnych, które potwierdzałyby istnienie dodatniej zależność między płynnością finansową a rentownością. Na uwagę zasługuje praca Z. Dreslera (2014: 227 i n.), w której wykazał na przykładzie przedsiębiorstw reprezentujących dwanaście różnych sektorów pozytywny związek między statycznymi miarami płynności finansowej a wskaźnikami rentowności. W tym miejscu należy zaznaczyć, że istnieją również ustalenia wskazujące na brak jakiejkolwiek zależności między rentownością a płynnością finansową (Jaworski i in., 2018: 62), to podtrzymuje potrzebę prowadzenia dalszych badań w tym zakresie. Oprócz wskazanych kierunków badań na uwagę zasługują również wyniki, które wskazują, że zależność między rentownością a płynnością finansową może mieć charakter nieliniowy, a dokładnie kształt odwróconego U (Gentry, 1976; Podilchuk, 2013; Kowerski, 2018).

Do nie mniej ważnych zagadnień poruszanych w literaturze należy poszukiwanie czynników kształtujących płynność finansową przedsiębiorstw funkcjonujących w różnych sektorach gospodarki. W literaturze można odnaleźć badania przeprowadzone m.in. dla przemysłu metalurgicznego (Sierpińska i Rzeszowski, 2012), spółdzielni mleczarskich (Domańska, 2016), przemysłu maszynowego (Lesáková i in., 2020). Innym obszarem badań podejmowanych w literaturze naukowej jest problematyka zarządzania płynnością finansową, która obejmuje 
m.in. zarządzanie kapitałem obrotowym netto, instrumentów finansowych wspomagających zarządzanie płynnością finansową, strategii płynności finansowej itp. (Kreczmańska-Gigol, 2010; Campello i in., 2010; Denčič-Mihajlov i Malenović, 2015; Szemraj i Czajkowska, 2020).

Wyodrębnione obszary badawcze związane z płynnością finansową, w ocenie autora, stanowią przykład najważniejszych problemów podejmowanych przez badaczy zarówno krajowych jak i tych zagranicznych.

\section{METODYKA BADANIA}

Każde przedsiębiorstwo, niezależnie do rodzaju prowadzonej działalności gospodarczej, powinno dążyć do zachowania płynności finansowej. Wraz ze zmniejszeniem się zdolności płatniczej przedsiębiorstwa rośnie ryzyko związane z utratą zdolności do kontynuowania działalności. Przyjęty w artykule cel badania, który koncentruje się na ocenie płynności finansowej przedsiębiorstwa Henryk Kania S.A. zrealizowano wykorzystując dwa podejścia w analizie płynności finansowej: ujęcie statyczne oraz dynamiczne płynności finansowej. Pierwsze z nich miało na celu ocenę płynności finansowej z punktu widzenia zdolności zamiany posiadanych aktywów obrotowych do pokrycia zobowiązań krótkoterminowych przedsiębiorstwa, z kolei drugie ocenę zdolności płatniczej na podstawie osiąganych przepływów pieniężnych. Uwzględnienie w ocenie płynności finansowej dwóch odmiennych podejść pozwoliło spojrzeć na płynność finansową przedsiębiorstwa w sposób kompleksowy bazując na danych finansowych pochodzących zarówno z bilansu, rachunku zysków i strat oraz rachunku przepływów pieniężnych. Uwzględniając podnoszony $\mathrm{w}$ artykule problem, który łączy się bezpośrednio $\mathrm{z}$ wypłacalnością przedsiębiorstwa, wymagał zbadania płynności finansowej zarówno w ujęciu krótkoterminowym, jak i długoterminowym. Tym samym ocenę zdolności płatniczej przedsiębiorstwa dokonano na podstawie relacji aktywów obrotowych i kapitałów krótkoterminowych w podejściu krótkoterminowym oraz relacji aktywów ogółem i kapitałów obcych w podejściu długoterminowym. Rozważania uzupełnione o analizę modeli dyskryminacyjnych w ocenie zdolności do kontynuacji działalności.

W artykule wykorzystano metodę doboru celowego przyjmując za obiekt badania Przedsiębiorstwo Zakłady Mięsne Henryk Kania S.A., które swoją historię na GPW w Warszawie rozpoczęły w 2012 roku dzięki przeprowadzonej fuzji z notowanymi na giełdzie Iławskimi Zakładami Naprawy Samochodów S.A. (IZNS S.A.). Historia Przedsiębiorstwa była o wiele dłuższa niż ta związana z giełdą, gdyż Zakłady Mięsne Henryk Kania powstały jako rodzinna firma w 1990 roku z siedzibą w Pszczynie, która przez wiele lat była rozwijana. Dynamiczny rozwój Przedsiębiorstwa zaowocował $\mathrm{z}$ jednej strony rosnącymi 
przychodami oraz zwiększonym udziałem w rynku, ale z drugiej strony narastającym zadłużeniem. Konsekwencją nadmiernego zadłużenia Przedsiębiorstwa był wzrost ryzyka finansowego, problemy $\mathrm{z}$ zachowaniem płynności finansowej, które ostatecznie doprowadziły do upadku Przedsiębiorstwa. Spółka chcąc się bronić przed upadłością w czerwcu 2019 roku wdrożyła przyspieszone postępowanie układowe powołując nadzorcę sądowego do przeprowadzenia restrukturyzacji Przedsiębiorstwa, jednakże sąd rok później zdecydował o upadłości likwidacyjnej Przedsiębiorstwa, tym samym o zakończeniu działalności gospodarczej.

Do wyznaczenia wskaźników pozwalających ocenić płynność finansową badanego Przedsiębiorstwa wykorzystano dane finansowe pochodzące ze sprawozdań finansowych Zakładów Mięsnych Henryk Kania S.A. obejmujące lata 20152019. W poszczególnych tabelach 1-4 ujęto podstawowe charakterystyki pozwalające na ocenę płynności finansowej oraz ryzyka utraty zdolności kontynuowania działalności gospodarczej przedsiębiorstwa.

\section{OCENA PŁYNNOŚCI FINANSOWEJ ZAKŁADÓW MIĘSNYCH HENRYK KANIA S.A. - CASE STUDY}

Ocenę płynności finansowej Zakładów Mięsnych Henryk Kania S.A. przeprowadzono wykorzystując do tego celu różne podejścia. W pierwszej kolejności na podstawie ujęcia majątkowo-kapitałowego zobrazowano zdolność przedsiębiorstwa do spłaty zobowiązań bieżących zamieszczając w tabeli 1 wielkość wskaźnika bieżącej płynności, wskaźnika podwyższonej płynności oraz wskaźnika płynności gotówkowej. Z zamieszczonych informacji w tabeli 1 wynika po pierwsze, iż zdolność płatnicza przedsiębiorstwa ulegała stopniowemu pogorszeniu w czasie, po drugie w 2019 roku Spółka ją utraciła, czego konsekwencją była upadłość Przedsiębiorstwa w 2020 roku. W 2015 roku aktywa bieżące Spółki przewyższały zobowiązania krótkoterminowe o 60\%, w kolejnych latach wskaźnik kształtował się znacznie niżej, w 2016 roku wielkość wskaźnika informowała, iż majątek obrotowy przewyższał zobowiązania bieżące o 45\%, w 2017 był poniżej 1 co oznaczało, że aktywa obrotowe tylko w części pokrywały zobowiązania bieżące. W 2018 roku wskaźnik bieżącej płynności wyniósł 1,13 co oznaczało, że aktywa obrotowe przewyższały zobowiązania krótkoterminowe o 13\%. Z poziomu wskaźnika podwyższonej płynności wynikało, że wartość płynnych aktywów przewyższała wartość bieżących zobowiązań jedynie w latach 2015-2016, w pozostałych była wyraźnie niższa od 1 . Z kolei wartość wskaźnika płynności gotówkowej oscylowała w granicach 0 , tym samym możliwość spłaty zobowiązań za pomocą posiadanych środków pieniężnych lub jej ekwiwalentów nie istniała. Zdolność Przedsiębiorstwa do spłaty zobowiązań uzależniona była od możliwości spieniężenia posiadanych aktywów lub pozyskania środków na rynku. 
Obraz płynności finansowej nakreślony przez wskaźniki bieżącej płynności oraz podwyższonej płynności finansowej w latach 2015-2018 był w rzeczywistości znacznie gorszy. Wskaźniki uwzględniały w swej konstrukcji wchodzące w zakres aktywów obrotowych należności z tytułu dostaw i usług oraz pozostałe należności krótkoterminowe, które to pozycje były trudne bądź też niemożliwe do upłynnienia. Jako przykład można wskazać prezentowaną w aktywach obrotowych pozycję pozostałe należności - zaliczkę na zakup udziałów w kwocie 96,5 mln zł przekazana w związku z przejęciem Staropolskich Specjałów Sp. z o.o. przez ZM Henryk Kania. Warunki rozliczenia transakcji były wielokrotnie aneksowane, w ten sposób przedłużano termin wymagalności należności, co pozwoliło Spółce prezentować wykazywaną w bilansie wierzytelność jako nierzeterminowaną. Ponadto podmiot, który otrzymał zaliczkę nie dokonał jej zwrotu pomimo tego, że Zakłady Mięsne Henryk Kania S.A. dokonały przejęcia spółki Staropolskie Specjały Sp. z o.o. Innym dowodem na to, że problemy z zachowaniem płynności finansowej w Przedsiębiorstwie pojawiły się o wiele wcześniej niż w 2019 roku, mogły być rosnące wierzytelności z tytułu dostaw i usług oraz ich koncentracja z jednym podmiotem - Rubin Energy Sp. z o.o. Wartość należności na koniec 2018 roku wyniosła 337,5 mln zł. Spółka wykazywała cały czas należności jako krótkoterminowe o terminie wymagalności od 1 do 3 miesięcy przesuwając terminy płatności należności na podstawie zawieranych porozumień. Taki sposób prezentacji informacji w sprawozdaniu finansowym w praktyce oznaczał, że aktywa obrotowe charakteryzowały się ograniczoną płynnością negatywnie wpływając na ocenę sytuacji płynnościowej Przedsiębiorstwa.

Problemy finansowe Zakładów Mięsnych Henryk Kania S.A. wynikały nie tylko z niewłaściwego zarządzania poszczególnymi elementami aktywów obrotowych, ale i ze znaczącego przyrostu zobowiązań krótkoterminowych w analizowanym horyzoncie czasu. Zobowiązania krótkoterminowe stanowiły główny element składowy wskaźników płynności finansowej. W ocenianym Przedsiębiorstwie główną składową zobowiązań bieżących były zobowiązania finansowe odsetkowe - kredyty bankowe oraz zobowiązania handlowe z tytułu dostaw i usług. Zwiększenie finansowania ze źródeł bankowych pozwalały Przedsiębiorstwu rozwiązać problemy w sposób doraźny. Znaczne uzależnienie od bankowych linii kredytowych doprowadziło do tego, że kapitał obrotowy będący w dyspozycji ZM Henryk Kania S.A. uzależniony był od decyzji przedłużających finansowanie z banków. Tym samym płynność finansowa Przedsiębiorstwa mogła być utrzymana do momentu, w którym Przedsiębiorstwo wykazywało zdolność do zaciągania bankowych źródeł finansowania. W momencie wypowiedzenia umów kredytowych przez banki w połowie 2019 roku Przedsiębiorstwo zostało odcięte od źródeł finansowania, które wykorzystywało do prowadzenia bieżącej działalności gospodarczej. W ten sposób znalazło się ono w bardzo trudnej sytuacji finansowej. Jednocześnie należy podkreślić, iż Zakłady Mięsne Henryk Kania S.A. 
dysponowały niewystarczającym kapitałem obrotowym netto na przestrzeni badanego okresu, który w coraz mniejszym stopniu brał udział w finansowaniu aktywów spółki. Sytuacja taka wskazywała na rosnące ryzyko utraty płynności finansowej w badanym Przedsiębiorstwie. W tym miejscu należy zaznaczyć, że nieumiejętne zarządzanie kapitałem obrotowym netto $\mathrm{z}$ reguły prowadzi do problemów z bieżącym regulowaniem wymagalnych zobowiązań.

Tabela 1. Wybrane wskaźniki krótkoterminowej płynności finansowej Zakładów Mięsnych Henryk Kania S.A. w latach 2015-2019

\begin{tabular}{|c|c|c|c|c|c|}
\hline Wyszczególnienie & 2015 & 2016 & 2017 & 2018 & 2019 \\
\hline Wskaźnik bieżącej płynności & 1,60 & 1,45 & 0,89 & 1,13 & 0,06 \\
\hline $\begin{array}{c}\text { Wskaźnik podwyższonej } \\
\text { płynności }\end{array}$ & 1,30 & 1,24 & 0,67 & 0,85 & 0,04 \\
\hline $\begin{array}{c}\text { Wskaźnik płynności } \\
\text { gotówkowej }\end{array}$ & 0,01 & 0,00 & 0,00 & 0,00 & 0,00 \\
\hline $\begin{array}{c}\text { Kapitał obrotowy netto } \\
\text { (KON) }\end{array}$ & 159653 & 183619 & -63966 & 77780 & -806957 \\
\hline $\begin{array}{c}\text { Udział KON w aktywach } \\
\text { ogółem }\end{array}$ & $26,16 \%$ & $22,87 \%$ & $\mathrm{x}$ & $6,50 \%$ & $\mathrm{x}$ \\
\hline
\end{tabular}

Źródło: opracowanie własne.

Z analizy krótkoterminowej płynności finansowej wynika, że przedsiębiorstwo w latach 2015-2018 wykazywało malejącą zdolność do spłaty bieżących zobowiązań, zaś w 2019 roku zdolność tą utraciło. Z punktu widzenia długoterminowej płynności finansowej można zauważyć podobne tendencje związane z kształtowaniem zdolności płatniczej w zakresie spłaty ogółu zobowiązań zaciągniętych przez Spółkę. Ryzyko utraty długoterminowej płynności finansowej rosło wraz ze wzrostem zadłużenia Jednostki. $Z$ wskaźnika ogólnego poziomu zadłużenia wynika, że Spółka z roku na rok w coraz większym stopniu zwiększała swoje zadłużenie. Zakłady Mięsne Henryk Kania S.A. w 2015 roku 64\% aktywów finansowało kapitałem obcym, w 70\% na koniec 2018 roku, zaś w 2019 roku wykorzystywało wyłącznie źródła obce ze względu na ujemne kapitały własne. Jeżeli znaczna część majątku Przedsiębiorstwa jest finansowana przy wykorzystaniu kapitałów obcych implikuje to wzrost ryzyka kredytowego, w tym ryzyka upadłości. Tym samym, aby uniknąć negatywnych skutków związanych z nadmiernym zadłużeniem należy dążyć do ukształtowania takiej struktury finansowania, która z jednej strony wspomagałaby rozwój Spółki, a z drugiej zapewniałaby długoterminową płynność finansową. Na podstawie reguł finansowych opisanych wskaźnikami pokrycia aktywów trwałych kapitałem własnym oraz pokrycia aktywów trwałych kapitałem stałym wynika, że zdolność Jednostki do zachowania płynności finansowej w aspekcie długoterminowym malała, a w 2019 roku została ona 
bezpowrotnie utracona. Zgodnie z zasadą pierwszą aktywa trwale wykorzystywane w Spółce powinny być finansowane kapitałami własnym, gdy zasada jest spełniona, wówczas relacje między wskazanymi pozycjami aktywów i pasywów uznaje się za prawidłowe, minimalizując $\mathrm{w}$ ten sposób ryzyko niewypłacalności Przedsiębiorstwa. Zakłady Mięsne Henryk Kania S.A. zasadę tę spełniały jedynie w 2015 i 2016 roku. W latach 2017-2018 wskaźnik ukształtował się poniżej 1, co oznaczało konieczność finansowania aktywów trwałych kapitałem obcym. W przypadku drugiej zasady, która jest mniej restrykcyjna od tej pierwszej, dopuszcza się finansowanie aktywów trwałych zobowiązaniami o charakterze długoterminowym. $Z$ zachowania tej relacji wynika, że w badanym Przedsiębiorstwie wystąpił problem z zachowaniem zdolności płatniczej w ujęciu długoterminowym. Zasada ta została spełniona jedynie w 2015 i 2016 roku, a następnie po tym okresie można mówić o kumulujących się problemach związanych z zachowaniem długoterminowej zdolności płatniczej Spółki. W 2017 roku aktywa trwałe w $88 \%$ były finansowane kapitałem stałym, zaś pozostała ich część była finansowana źródłami obcymi krótkoterminowymi. W 2018 roku wskaźnik ukształtował się powyżej 1. Ze zmian wskaźnika w czasie można było zauważyć, że pokrycie aktywów trwałych kapitałem stałym wyraźnie zmniejszyło się po 2016 roku. Na uwagę zwraca przede wszystkim negatywna wymowa poziom wskaźnika poniżej 1, gdyż determinuje to negatywną ocenę płynności finansowej badanego Przedsiebiorstwa oraz wzrost ryzyko finansowego zarówno akcjonariuszy, jak i wierzycieli. Wskaźniki pokrycia aktywów trwałych kapitałem własnym oraz pokrycia aktywów trwałych kapitałem stałym dla 2019 roku uwidaczniały niewypłacalność Przedsiębiorstwa. Kapitały własne przyjęły wartość ujemną, tym samym pasywa stanowiły większą wartość niż jego aktywa. Majątek Spółki był niewystarczający do tego, aby uregulować wszystkie zaciągnięte przez jednostkę zobowiązania. Wdrożone postępowanie restrukturyzacyjne przez Przedsiębiorstwo okazało się nieskuteczne. Na skutek utraty płynności finansowej Jednostki stało się niewypłacalne, a tym samym w 2020 roku ogłoszono upadłość likwidacyjną Przedsiębiorstwa.

Tabela 2. Wybrane wskaźniki długoterminowej płynności finansowej Zakładów Mięsnych Henryk Kania S.A. w latach 2015-2019

\begin{tabular}{|c|r|r|r|r|r|}
\hline Wyszczególnienie & 2015 & 2016 & 2017 & 2018 & 2019 \\
\hline Wskaźnik pokrycia aktywów trwałych kap. własnym & 1,19 & 1,29 & 0,56 & 0,70 & $-1,90$ \\
\hline Wskaźnik pokrycia aktywów trwałych kap. stałym & 1,86 & 1,89 & 0,88 & 1,15 & $-1,90$ \\
\hline Wskaźnik ogólnego poziomu zadłużenia & 0,64 & 0,67 & 0,72 & 0,70 & 2,62 \\
\hline Trwałość struktury finansowania & 0,57 & 0,49 & 0,45 & 0,50 & $-1,62$ \\
\hline
\end{tabular}

Źródło: opracowanie własne. 
Statyczny obraz płynności finansowej Przedsiębiorstwa można uzupełnić o ocenę dynamiczną wykorzystując do tego celu rachunek przepływów pieniężnych. Ze względu na charakter uzyskiwanych przez Przedsiębiorstwo przepływów pieniężnych, które uniemożliwiały wyznaczenie wszystkich wskaźników płynności dynamicznej m.in. wskaźnika zdolności wypracowania środków pieniężnych netto z działalności operacyjnej, wskaźnika zależności od zewnętrznych źródeł finansowania czy wskaźnika ogólnej wystarczalności środków pieniężnych, do oceny płynności dynamicznej wykorzystano analizę strumieni przepływów pieniężnych uzyskiwanych w ramach działalności operacyjnej, inwestycyjnej i finansowej. Z punktu widzenia dynamicznej płynności finansowej na szczególną uwagę zasługują przepływy pieniężne uzyskiwane w ramach działalności operacyjnej. Charakter przepływów z działalności operacyjnej Przedsiębiorstwa decyduje o tym, czy prowadzona podstawowa działalności przynosi zyski oraz generuje odpowiednią wielkość własnych środków pieniężnych. W prawidłowo funkcjonującym przedsiębiorstwie przepływy operacyjne powinny być dodatnie, to one powinny być głównym źródłem dopływu środków pieniężnych.

Tabela 3. Przepływy środków pieniężnych Zakładów Mięsnych Henryk Kania S.A. w latach 2015-2019 w tys. zł

\begin{tabular}{|l|r|r|r|r|r|}
\hline \multicolumn{1}{|c|}{ Wyszczególnienie } & \multicolumn{1}{c|}{2015} & \multicolumn{1}{c|}{2016} & \multicolumn{1}{c|}{2017} & \multicolumn{1}{c|}{2018} & \multicolumn{1}{c|}{2019} \\
\hline Przepływy pieniężne ogółem, & 2543 & -1918 & -406 & 799 & 7724 \\
w tym z: & & & & & \\
- działalności operacyjnej & -23187 & -29663 & 38 & 48213 & -703511 \\
- działalności inwestycyjnej & -5633 & -25720 & -9899 & -3403 & 7724 \\
- działalności finansowej & 31363 & 53465 & 9455 & -44011 & 695787 \\
\hline
\end{tabular}

Źródło: opracowanie własne.

W badanym Przedsiębiorstwie przepływy pieniężne z działalności operacyjnej najczęściej przyjmowały wartości ujemne. Przepływy z działalności operacyjnej w Zakładach Mięsnych Henryk Kania kształtowane były przede wszystkim przez zmiany stanu zapasów, należności oraz zobowiązań (szczegółowe dane kształtujące przepływy pieniężne w badanym Przedsiębiorstwie nie zostały zamieszczone w artykule). W badanym Przedsiębiorstwie na ujemne saldo środków pieniężnych z działalności operacyjnej największy wpływ miał rosnący stan utrzymywanych zapasów oraz wzrost poziomu kredytowania odbiorców. Ujemne przepływy $\mathrm{z}$ działalności operacyjnej utrzymywane $\mathrm{w}$ długim terminie $\mathrm{z}$ reguły oznaczają dla Spółki problemy finansowe, co miało miejsce w przypadku analizowanego przypadku. Przedsiębiorstwo chcąc kontynuować działalność gospodarczą zmuszone było uzupełniać brakujące środki, pozyskuje je w ramach działalności finansowej poprzez zaciągnięcie kredytów i pożyczek oraz emisję 
obligacji. Narastające zadłużenie zwrotne w powiązaniu z ujemnymi przepływami z działalności operacyjnej doprowadziło do sytuacji, w której jego przyszła działalność była uzależniona od pozyskania dalszego finansowania bankowego, to determinowało w sposób istotny zagrożenie utraty płynności finansowej Przedsiębiorstwa.

Utrata płynności finansowej przez przedsiębiorstwo stwarza duże ryzyko jego niewypłacalności, która prowadzi z reguły do upadłości jednostki. Do oceny zdolności kontynuacji działalności Przedsiębiorstwa w praktyce wykorzystuje się modele predykcji upadłości. Za pomocą funkcji dyskryminacyjnej dokonuje się oceny ogólnej sytuacji finansowej przedsiębiorstwa oraz wskazuje się na zagrożenie upadłości podmiotu gospodarczego. Modele predykcji upadłości bazują na określonym zestawie wskaźników finansowych, często wśród których znajdują się miary płynności finansowej. $Z$ tego też względu modele dyskryminacyjne mogą pełnić rolę uzupełniającą ocenę zdolności płatniczej przedsiębiorstwa.

Tabela 4. Wybrane modele predykcji upadłości dla Zakładów Mięsnych Henryk Kania S.A. w latach 2015-2019

\begin{tabular}{|c|r|r|r|r|r|}
\hline Wyszczególnienie & \multicolumn{1}{|c|}{2015} & \multicolumn{1}{|c|}{2016} & \multicolumn{1}{c|}{2017} & \multicolumn{1}{c|}{2018} & \multicolumn{1}{c|}{2019} \\
\hline Model D. Appenzeller, K. Szarzec & 0,79 & 0,68 & 0,21 & 0,44 & $-7,08$ \\
\hline Model J. Gajdki, D. Stosa & 0,04 & 0,00 & $-0,04$ & $-0,03$ & $-7,25$ \\
\hline Model T. Maślanki & 0,82 & 0,70 & 0,33 & 0,51 & $-13,79$ \\
\hline Model E. Mączyńskiej & 2,07 & 1,79 & 1,20 & 1,53 & $-36,63$ \\
\hline Model M. Hamrol, B. Czajka, M. Piechocki & 1,95 & 1,48 & 0,35 & 0,61 & $-15,12$ \\
\hline Model B. Prusaka & 0,59 & 0,41 & $-0,01$ & 0,06 & $-14,24$ \\
\hline
\end{tabular}

Wartości graniczne funkcji dyskryminacyjnych: model D. Appenzeller, K. Szarzec $Z<0-$ „,bankrut”; $Z \geq 0$ - „niebankrut”, model J. Gajdki, D. Stosa $Z \leq 0$ - „bankrut”; -0,49<Z<0,49 - obszar nieokreślony, $Z \geq 0$,,niebankrut”, model T. Maślanki $Z<0$ - „,bankrut”; $Z \geq 0$ - ,niebankrut”, model E. Maczyńskiej $Z<0$ - „bankrut”; $Z \geq 0$ - ,niebankrut”, model M. Hamrol, B. Czajka, M. Piechocki $\mathrm{Z}<0$ - „,bankrut”; $\mathrm{Z} \geq 0$ - „niebankrut”, model B. Prusaka $Z \leq-0,13$ - „,bankrut”; $-0,13<Z<0,65$ obszar nieokreślony, $\mathrm{Z} \geq 0,65$,niebankrut”.

Źródło: opracowanie własne.

Z wartości funkcji dyskryminacyjnych zobrazowanych w tabeli 4 dla analizowanego Przedsiębiorstwa wynika, że zastosowane modele były zbieżne w ocenie co do pogarszającej się sytuacji finansowej Spółki. Wszystkie modele wskazywały na rosnące ryzyko upadłości Przedsiębiorstwa, a co za tym idzie na problemy z zachowaniem zdolności płatniczej. Żaden z analizowanych modeli w latach 2015-2018 nie przypisał Zakładów Mięsnych Henryk Kania S.A. do grupy bankrutów. Model Gajdki i Stosa oraz model Prusaka wskazywał na obszar, 
w którym trudno było jednoznacznie określić standing finansowy Przedsiębiorstwa. Z kolei w 2019 roku wszystkie modele dyskryminacyjne wyraźnie wskazywały, że sytuacja finansowa Spółki była bardzo zła, a ryzyko utraty zdolności do kontynuowania działalności bardzo duże. Znalazło to swoje potwierdzenie w tym, że wobec Spółki sąd ogłosił postanowienie o upadłości likwidacyjnej Przedsiębiorstwa, które zakończyło ponad 30 - letnią historię jego działalność.

\section{PODSUMOWANIE}

Studium przypadku Zakładów Mięsnych Henryk Kania S.A. dowodzi, iż problemy z zachowaniem zdolności płatniczej Przedsiębiorstwa mogą prowadzić do jego upadłości. Warunkiem kontunuowania działalności gospodarczej Przedsiębiorstwa jest utrzymanie płynności finansowej. Warunku tego badane Przedsiębiorstwo nie spełniło. Z przeprowadzonej analizy płynności finansowej ZM Henryk Kania wynika, że problemy z zachowaniem zdolności płatniczej Przedsiębiorstwa narastały w czasie. Ocena płynności finansowej z punktu widzenia płynności statycznej oraz dynamicznej, a także analiza dyskryminacyjna prowadziła do tych samych spostrzeżeń wskazując na rosnące ryzyko jej utraty. Zdolność Przedsiębiorstwa do spłaty zobowiązań krótkoterminowych nieustannie ulegała pogorszeniu. Aktywa obrotowe w coraz to mniejszym stopniu pokrywały bieżące zobowiązania. Ryzyko utraty płynności finansowej rosło wraz ze zmniejszaniem się poziomu kapitału obrotowego netto.

Uwzględniając podejście długoterminowe w ocenie statycznej płynności finansowej, Przedsiębiorstwo wykazywało pogarszającą zdolność spłaty wszystkich zobowiązań. Ryzyko utraty długoterminowej płynności finansowej zwiększało się wraz ze wzrostem zadłużenia Przedsiębiorstwa. W 2019 roku w Przedsiębiorstwie kapitały własne przyjęły ujemną wartość, co oznaczało, że zobowiązania spółki były większe od wartości posiadanego majątku. Z punktu widzenia płynności długoterminowej Przedsiębiorstwo stało się niewypłacalne.

ZM Henryk Kania wykazywało niską zdolność do wypracowywania własnych środków z prowadzonej działalności, w całym badanym okresie przeważały ujemne przepływy pieniężne osiągane z działalności operacyjnej. Niewystarczający poziom środków pieniężnych wyrównywany był środkami pozyskiwanymi w ramach działalności finansowej, głównie poprzez zaciąganie kredytów, pożyczek oraz emisję obligacji. To prowadziło do niebezpiecznego zjawiska - nadmiernego zadłużenia, które determinowało zagrożenie kontynuowania działalności gospodarczej. Tym samym na podstawie analizy krótkookresowej i długookresowej oceny zdolności płatniczej można było zaobserwować wyraźny wzrost ryzyka, który towarzyszył działalności gospodarczej. Zachowanie ciągłości działania Przedsiębiorstwa w takiej sytuacji było niemożliwe. 
Płynność finansowa stanowi jeden z ważniejszych obszarów oceny działalności Przedsiębiorstwa, albowiem należy ona do grupy zasadniczych czynników warunkujących jego dalsze funkcjonowanie. Oceną zdolności płatniczej zainteresowani są w szczególności wierzyciele, którzy odczuwają skutki utraty płynności finansowej przez Przedsiębiorstwo w ten sposób, że nie otrzymują w terminie lub w ogóle zapłaty za dostarczone towary, wyroby gotowe, usługi. Problem dotyka również akcjonariuszy, którzy mogą utracić cały zaangażowany kapitał, kiedy to nierozwiązane trudności z utrzymaniem płynności finansowej Przedsiębiorstwa prowadzą do jego upadłości. Ukazany przypadek Przedsiębiorstwa ZM Henryk Kania S.A. dowodzi, że problemy związane z utratą płynności finansowej mogą dotyczyć każdego Przedsiębiorstwa, w tym i takiego o ugruntowanej pozycji rynkowej czy osiąganych corocznych przychodach w wysokości powyżej 1 mld złotych.

Przykład Zakładów Mięsnych Henryk Kania dowodzi, iż wysiłki menedżerów powinny koncentrować się przede wszystkim na zapewnieniu Przedsiębiorstwu płynności finansowej będącej warunkiem kontynuacji działalności jednostki gospodarczej oraz realizacji założonych celów. Bieżące monitorowanie zdolności płatniczej pozwala Przedsiębiorstwu uniknąć niewypłacalności, z kolei dobór odpowiednich narzędzi badawczych do pomiaru płynności finansowej warunkuje prawidłową i obiektywną ocenę sytuacji płynnościowej Przedsiębiorstwa. Studium przypadku przedstawione $\mathrm{w}$ artykule miało na celu podkreślenie ważności podjętego problemu w kontekście obecnej sytuacji gospodarczej wywołanej pandemią Covid-19, która doprowadziła do pogorszenia zdolności płatniczej wielu Przedsiębiorstw.

\section{BIBLIOGRAFIA}

Bednarski, L. i Waśniewski T., red. (1996). Analiza finansowa w zarządzaniu przedsiębiorstwem. Warszawa: Fundacja Rozwoju Rachunkowości w Polsce.

Burzykowska, M. (2006). Rozważania o zdolności płatniczej, płynności finansowej i wypłacalności przedsiębiorstwa. Acta Universitatis Lodziensis. Folia Oeconomica, 200, ss. 79-90.

Bolek, M. i Wiliński, W. (2012). The influence of liquidity on profitability of polish construction sector companies. E-Finanse: Financial Internet Quarterly, 8(1), ss. 38-52.

Campello, M., Giambona, E., Graham, J.R. i Harvey, C.R. (2010). Liquidity Management and Corporate Investment During a Financial Crisis, NBER Working Paper, 16309, ss. 1944-1979.

Denčič-Mihajlov, K. i Malenović, M. (2015). Corporate liquidity management: implications and determinants, Facta Universitatis, Series: Economics and Organization, 12(2), ss. 157-170.

Domańska, T. (2016). Determinanty płynności finansowej spółdzielni mleczarskich. Zarzązanie Finansami i Rachunkowość, 4(4), ss. 41-51.

Dresler, Z. (2014). Rentowność przedsiębiorstw w Polsce. Kraków: Wydawnictwo Uniwersytetu Ekonomicznego w Krakowie.

Gentry, J.A. (1976). Management perceptions of the working capital process, Urbana-Champaign: College of Commerce and Business Administration, University of Illinois at Urbana-Champaign. 
Guzik, B. (2006). Statystyczne metody badania związków między rentownością a płynnością bankową. Badania Operacyjne i Decyzje, 3-4, ss. 57-68.

Jaworski, J., Czerwonka, L. i Mądra-Sawicka, M. (2018). Zależność między rentownością a płynnością finansową w sektorze przetwórstwa spożywczego w Polsce. Roczniki Naukowe Stowarzyszenia Ekonomistów Rolnictwa i Agrobiznesu, 20(1), ss. 58-63.

Karbownik, L. (2012). Pojęcie i obszary kreowania oraz zapewnienia bezpieczeństwa finansowego przedsiębiorstwa. Acta Universitatis Lodziensis, Folia Oeconomica, 267, ss. 63-67.

Kowerski, M. (2018). Zależność między rentownością a płynnością finansową ma kształt odwróconego U. Prace Naukowe Uniwersytetu Ekonomicznego we Wrocławiu, 440, ss. 338-348.

Kreczmańska-Gigol, K. (2010). Aktywne zarządzanie plynnościa finansowa przedsiębiorstwa. Warszawa: Difin.

Kuciński, A. (2018a). Analiza i ocena płynności strukturalnej przedsiębiorstwa na przykładzie spólek z branży obuwniczej notowanych na GPW w Warszawie w latach 2015-2016. Finanse, Rynki Finansowe, Ubezpieczenia, 4(94/1), ss. 131-142, doi: 10.18276/frfu.2018.94/1-12.

Kuciński, A. (2018b). Wypłacalność przedsiębiorstwa z punktu widzenia płynności finansowej i zadłużenia. Przedsiębiorczość i Zarządzanie, XIX 4(1), ss. 119-131.

Kusak, A. (2006). Ptynność finansowa: analiza i sterowanie. Warszawa: Wydawnictwo Naukowe Wydziału Zarządzania Uniwersytetu Warszawskiego.

Lesáková, L., Vinczeova, M. i Špiner, V. (2020). Factors determining the liquidity of companies in the mechanical engineering industry in Slovakia - an empirical study. Forum Scientiae Oeconomia, 8(3), ss. 33-47.

Michalski, G. (2010). Strategiczne zarządzanie plynnościa finansowa w przedsiębiorstwie. Warszawa: Wydawnictwo CeDeWu.

Podilchuk, Z. (2013). Impact of liquidity management on profitability. Evidence from Ukraine. Kyiv: Kyiv School of Economics.

Sierpińska, M. i Jachna, T. (1993). Ocena przedsiębiorstwa wedlug standardów światowych. Warszawa: Wydawnictwo PWN.

Sierpińska, M. i Rzeszowski, P. (2012). Determinanty płynności finansowej w przemyśle metalurgicznym. Zeszyty Naukowe Uniwersytetu Szczecińskiego, Finanse, Rynki Finansowe, Ubezpieczenia, 50, ss. 197-208.

Stępień, K. (2013). W poszukiwaniu ładu terminologicznego: zdolność płatnicza, płynność finansowa, wypłacalność. Zeszyty Naukowe Uniwersytetu Ekonomicznego w Krakowie, 908, ss. 93-102.

Szemraj, T. i Czajkowska, A. (2020). Taktyki i strategie zarzadzania kapitatem obrotowym w finansowaniu przedsiębiorstw. Łódź: Wydawnictwo Uniwersytetu Łódzkiego.

Waściński, T. i Kruk, M. (2010). Analiza powiązań pomiędzy rentownością i płynnością spółek branży cukierniczej notowanych na GPW w Warszawie. Zeszyty Naukowe Akademii Podlaskiej w Siedlcach. Seria: Administracja i Zarzadzanie, 84, ss. 9-20.

Wędzki, D. (2003). Strategie plynności finansowej przedsiębiorstwa. Przepływy pieniężne a wartość dla właścicieli. Kraków: Oficyna Ekonomiczna.

Witczak, I. (2014). Płynność finansowa jako miara sprawności funkcjonownia firm farmaceutycznych. Studia Ekonomiczne Zeszyty Naukowe Uniwersytetu Ekonomicznego w Katowicach, 201, ss. 415-423. 


\section{UTRZYMANIE PŁYNNOŚCI FINANSOWEJ W PRZEDSIĘBIORSTWIE JAKO WARUNEK KONTYNUACJI JEGO DZIAŁALNOŚCI NA PRZYKŁADZIE ZAKŁADÓW MIĘSNYCH HENRYK KANIA S.A.}

\section{Streszczenie}

W warunkach zwiększonej niepewności, w której przyszło funkcjonować współczesnym przedsiębiorstwom, utrzymanie płynności finansowej stało się priorytetem. Posiadanie płynności finansowej przez przedsiębiorstwo warunkuje ciągłość działania oraz jego rozwoju. W artykule na podstawie studium przypadku przedsiębiorstwa Zakłady Mięsne Henryk Kania S.A. przeanalizowano kształtowanie się zdolności płatniczej przedsiębiorstwa w latach 2015-2019 wykorzystując ujęcie krótkoterminowe i długoterminowe w ocenie płynności finansowej. Uwidoczniony przykład wskazuje, że problemy związane z utrzymaniem płynności w przedsiębiorstwie mogą prowadzić do upadłości przedsiębiorstwa.

Słowa kluczowe: płynność finansowa, przedsiębiorstwo, zdolność. 